\title{
Pembentukan dan Pemberlakuan AAUPPL Melalui Penyelenggaraan Pemerintahan dalam Rangka Menjelmakan Pemerintahan yang Baik dan Bersih di Indonesia
}

\author{
S.F. Marbun
}

\begin{abstract}
The general principles making and expiry of good governance through governmental actions has an important thing for national life its implementation jurisdictionaly and sociologically as a political norm for bureaucracy in the central or provincial government has been regulated by a presidential and governor decree which based upon conventional practices of governance. The impact of neglecting this matter would cause any dismissal by Administrative Court.
\end{abstract}

\section{Pendahuluan}

Pembentukan dan pemberlakuan Asasasas Umum Penyelenggaraan Pemerintahan yang Layak (AAUPPL) melalui penyelenggaraan pemerintahan, mempunyai arti sangat penting bagi kehidupan bernegara bangsa Indonesia, utamanya bagi terjelmanya penyelenggaraan pemerintahan yang baik (good government) dan bersih (clean government). Selain itu, pembentukan dan pemberlakuan AAUPPL akan memberikan isi dan corak bagi pertumbuhan dan perkembangan Negara Hukum Indonesia sebagai negara hukum modern.

Benih-benih AAUPPL tersebut seharusnya tumbuh dan bertunas mengeluarkan cabang serta ranting dari batang pohon Negara Hukum Indonesia, sehingga di bawah naungan batang pohon Negara Hukum Indonesia dan di bawah cabang, ranting serta daun-daun nan rindang dari AAUPPL, diharapkan terjelma penyelenggaraan pemerintahan yang baik dan bersih, di Pusat dan di Daerah. Sebaliknya, sulit menjelmakan penyelenggaraan pemerintahan yang baik dan bersih selama AAUPPL belum tumbuh dan berkembang dalam penyelenggaraan pemerintahan Indonesia; bahkan patut dikhawatirkan Negara Hukum Indonesia akan tumbuh bagaikan pohon kering yang meranggas, tidak bercabang, tidak berdaun, tidak berbunga dan tidak 
berbuah, sedangkan batangnya di tengahtengah akan digerogoti oleh kumbang dan rayap. Oleh karena itu, tulisan ini merupakan salah satu usaha untuk menggali dan menemukan cara pembentukan dan pemberlakuan' AAUPPL dalam penyelenggaraan pemerintahan di Indonesia.

\section{Rentan Penyakit Kronis}

Pemerintahan Orde Baru sejak awal telah mencanangkan keinginan untuk menjelmakan penyelenggaraan pemerintahan yang baik dan bersih, utamanya sebagai andalan mengatasi berbagai rintangan yang akan menghadang kehidupan bangsa Indonesia mencapai masyarakat adil dan makmur, ${ }^{1}$ namun harapan tersebut tetap merupakan impian yang tidak kunjung terwujudkan sampai pada era reformasi sekarang ini. ${ }^{2}$
Beberapa faktor penyebabnya antara lain politik hukum Orde Baru sangat banyak memberikan wewenang bebas kepada pemerintah (vrijs bestuur). untuk mengatur berbagai hal melalui peraturan perundangundangan di bawah undang-undang (delegating proviso), ${ }^{3}$ dan memberikan wewenang melakukan interpretasi terhadap peraturan pelaksanaannya. ${ }^{4}$ Akibatnya, pejabat administrasi negara dengan bebas dan tanpa batas menggunakan wewenang bebas tersebut (freies Ermessen), sehingga menimbulkan berbagai penyakit kronis dalam penyelenggaraan pemerintahan, seperti penyakit korupsi, kolusi dan nepotisme yang dapat melemahkan berbagai sendi kehidupan bermasyarakat, berbangsa dan bernegara.

Demikian juga berbagai tindakan sewenang-wenang (willekeur/a bus de droit) dan penyalahgunaan wewenang

'Lihat Pidato Soepardjo Rustam yang dipetik oleh Mochtar Lubis. 1985."Kata Pengantar." Dalam Bunga Rampai Korupsi, Jakarta: LP3ES. HIm: xil-xxiii. Disampaikan pada pidato Wisuda Sarjana Institut IImu Pemerintahan Dalam Negeri 1984.

${ }^{2}$ Lihat Ketetapan Majelis Permusyawaratan Rakyat No. XI/MPR/1998 tentang Penyelenggaraan Negara yang Bersih dan Bebas Korupsi, Kolusi dan Nepotisme jo. Undang-undang No. 28 Tahun 1999 tentang Penyelenggaraan Pemerintahan yang Bersih dan Bebas Korupsi, Kolusi dan Nepotisme.

${ }^{3}$ Lihat Moh. Fajrul Falaakh. 1994. Laporan Penelitian Survey Delegating Proviso dalam Undangundang Indonesia, 1966-1992. Pusat Antar Universitas Studi Sosial. Jogjakarta: Universitas Gadjahmada. Hasil penelitian tersebut menunjukkan selama periode 1966-1992, dari 178 Undang-Undang yang diteliti ternyata 144 Undang-Undang $(80,89 \%)$ mengandung delegating proviso dan hanya 34 Undang-Undang $(19,11 \%)$ tidak mengandung delegating proviso. Bahkan dilihat dari segi persyaratan dalam pelimpahan wewenang tersebut. ternyata secara keseluruhan lebih banyak ditemukan pelimpahan tak bersyarat (unconditioned delegating proviso) yakni 1.036 kali $(94,61 \%)$ dari delegating proviso yang ada, sedangkan pelimpahan wewenang bersyarat (conditioned delegating proviso) 59 kali $(5,39 \%)$.

"Lihat Moh Mahfud, MD. 1993. "Perkembangan Politik Hukum. Studi tentang Pengarun Konfigurası Politik Terhadap Produk Hukum di Indonesia." Disertasi. Jogjakarta: Universitas Gadjahmada. Konfigurasi Polititik Pemerintah Orde Baru adalah non demokratis dengan karakteristik produk hukumnya konservatif ortodoks. 
(detournement de pouvoir) serta perbuatan melawan hukum (onrechtmatige overheidsdaad), dengan mudah dilakukan oleh pejabat administrasi negara. Mereka tidak lagi dapat membedakan antara kepentingan dinas dan kepentingan pribadi, milik pemerintah dan milik pribadi, kekuasaan politik sering dianggap sebagai bagian dari milik pribadi yang dapat dieksploitasi dengan menarik berbagai pungutan. Akhirnya, mereka sangat rentan terhadap berbagai penyakit kronis, seperti korupsi, upeti, komisi, sogok dan nepotisme. Bahkan korupsi telah merasuk ke dalam kehidupan politik dan menimbulkan korupsippolitik.- =

Tümbūh dan berkembangnya tindakan pejabat administrasi negara tersebut, salah satu sebabnya belum berperannya AAUPPL dalam penyelenggaraan pemerintahan, seperti asas kepastian hukum, asas persamaan, asas kecermatan, asas kejujuran atau asas keterbukaan atau asas fair play, asas larangan sewenang-wenang dan asas larangan menyalahgunakan wewenang. Oleh karena itu, sulit menjelmakan penyelenggaraan pemerintahan yang baik dan bersih di Pusat dan di Daerah. Sulit menopang setiap usaha reformasi yang dilakukan untuk membersihkan tubuh bangsa ini dari berbagai penyakit kronis tersebut, selama belum diperhatikannya dengan sungguh-sungguh peranan AAUPPL dalam penyelenggaraan pemerintahan.

\section{AAUPPL sebagai Hukum Tidak Tertulis}

Eksistensi AAUPPL sebagai hukum tidak tertulis dijamin secara konstitusional di dalam
Penjelasan UUD 1945. Dalam Penjelasan tersebut dinyatakan bahwa di samping UUD 1945 berlaku juga hukum dasar yang tidak tertulis, yaitu aturan-aturan dasar yang timbul dan terpelihara dalam praktek penyelenggaraan negara, meskipun tidak tertulis.

Di lingkungan hukum tata negera istilah hukum tidak tertulis tersebut lazim disebut konvensi (convention), namun AAUPPL sebagai hukum tidak tertulis tidak dapat disamakan dengan konvensi ketatanegaraan (conventions of the constitution), seperti dalam hukum konstitusi Inggris. Konvensi ketatanegaraan demikian ini tidak tergolong kaidah hukum yang pelaksanaan atau pentaatannya dapat dipaksakan melalui pengadilan apabila terjadi pelanggaran terhadapnya. Oleh karena itu, AAUPPL sebagai hukum tidak tertulis lebih tepat disamakan dengan hukum tata negara tidak tertulis, yakni sebagai bagian dari Hukum Konstitusi (the law of the constitution). Termasuk ke dalamnya adalah putusan-putusan hakim (judge made maxim), keputusan-keputusan yang berasal dari kebiasaan (custom) dan adat turuntemurun (tradition). Pelaksanaan dan pentaatan terhadapnya dapat dipaksakan melalui (oleh) pengadilan apabila terjadi pelanggaran.

\section{AAUPPL sebagai Asas Hukum}

Pada awal diperkenalkannya istilah AAUPPL di Belanda, Wiarda menyebut karakteristik AAUPPL sebagai tendensitendensi etik yang mendasari hukum administrasi tertulis dan tidak tertulis dalam praktek pemerintahan, ${ }^{5}$ sedangkan Komisi de

${ }^{5}$ A.M.A. Maasen. tanpa tahun. De Algemmene Beginselen van Berhoorlijk Bestuur. NN, Samsomn. V. Alphenaan Denrijn. Hilm. 24. 
Monchy menyebutnya sebagai kecenderungan moral pemerintahan umum. ${ }^{6}$ Persoalannya, apakah pengertian AAUPPL sebagai tendensi etik dalam praktek pemerintahan sama dengan pengertian AAUPPL sebagai kecenderungan moral pemerintahan umum?

Secara epistimologi kata etika berasal dari bahasa Latin ethos, artinya adat kebiasaan, sedangkan kata moral berasal dari bahasa Latin mos (jamak) atau mores, artinya cara hidup atau adat istiadat atau kebiasaan baik. ${ }^{7}$ Dengan demikian, makna etika setara atau sinonim dengan makna moral, meskipun keduanya berasal dari dua istilah yang berbeda. ${ }^{8}$ Pendapat demikian ini sejalan dengan pendapat $\mathrm{H}$. Devos ${ }^{9}$ dan A. Fagothey. ${ }^{10}$

Sebaliknya, pengertian AAUPPL sebagai kecenderungan etis tidak sinonim dengan pengertian AAUPPL sebagai kecenderungan moral pemerintahan umum. Sebab, dilihat dari hubungannya terdapat perbedaan antara makna etika, moral dan moralitas. Menurut Robert C. Solomon, etika di samping sebagai bagian dari filsafat yang mempelajari nilai-nilai yang dianut oleh manusia, juga sebagai fokus dalam disiplin ilmu itu sendiri yang berkaitan dengan nilai-nilai hidup (hukum) yang mengatur tingkah laku manusia. Oleh karena itu, oleh Robert C Salomon" "etika khusus yang berfokus pada hukum dan prinsip-prinsip yang abstrak yang mengatur tingkah laku manusia disebutnya moralitas, sedangkan moral dalam pengertian umum berfokus pada karakter dan sifat-sifat individu yang khusus yang tidak terdapat di dalam peraturan-peraturan hukum.

Dalam maknanya yang terakhir ini makna AAUPPL sebagai hukum kecenderungan etis menurut Wiarda, tidak sinonim dengan makna AAUPPL sebagai kecenderungan moral pemerintahan umum sebagaimana dirumuskan oleh Komisi de Monchy. Sebab. etika sebagai moralitas fokusnya adalah hukum, sedangkan moral pemerintahan fokusnya adalah karakter dan sifat pejabat administrasi negara secara individual, yang tidak terdapat di dalam peraturan. Arahannya, hanya ditujukan kepada sikap bathin pejabat administrasi negara agar memiliki budi pekerti yang luhir, rasa malu, dan rasa bersalah. Dengan demikian, AAUPPL bukan merupakan kecenderungan etis dan kecenderungan moral pemerintahan umum, tetapi AAUPPL merupakan bagian dari hukum, karena arahannya ditujukan kepada sikap lahir pejabat administrasi negara dengan disertai hak dan kewajiban yang bersifat memaksa,

${ }^{6}$ D. van Wijk \& Willem Konijnenbelt. 1988. Hoofdstukken van Administratitief Recht, Breda. HIm. 75.

'E.Sumaryono. 1995. Etika Profesi Hukum, Norma-norma Bagi Penegak Hukum. Jogjakarta: Kanisius. HIm. 12; Lihatjuga Wahyudi Kumorotomo. 1992. Etika Administrasi Negara. Jakarta: Rajawali Press. Him. 56. Dari istilah moral ini kemudian muncul istilah morae atau morilyang artinya jauh dari pengertian asalnya. Moril dapat berarti semangat atau dorongan bathin.

${ }^{8}$ The Liang Gie. 1986. Etika Administrasi Pemerintahan. Universitas Terbuka. HIm. 19.

'Lihat H. Davos. 1967. "Inleiding tot de Ethiek" (alih bahasa) Soeijono Soemargono. Pengantar Etika. Jogjakarta: Tiara Wacana. HIm. 1.

:A. Faatgothey Austin; Right and Reazon dalam E. Suamyono. Pengantar... Loc.Cit.

"Robert E. Solomon. 1987. Etika Suatu Pengantar. Jakarta: Erlangga. HIm. 2-18. 
sanksi yang tegas dan konkrit bagi yang melanggarnya.

Ditinjau dari filsafat hukum ditemukan hubungan dan persamaan antara tatanan etika atau moral dengan tatanan hukum, meskipun diakui, hubungan tersebut tidak persis sama dan menjadi satu. Oleh karena itu, tidak dapat dinyatakan tatanan moral adalah tatanan hukum dan sebaliknya. ${ }^{12}$ Sebab, menurut Adolf Reinach terdapat perbedaan antara tatanan etis atau moral dengan tatanan hukum. Norma moral (etis) melekat pada manusia sebagai pribadi dan lebih bersifat kehidupan bathin yang tidak dapat dipindahkan atau dihilangkan, sedangkan norma hukum (yuridis) lebih ditujukan kepada kehidupan ekstern yang berasal dari suatu perjanjian, sehingga dapat diserahkan kepada orang lain dan dapat hilang apabila tidak digunakan.

Ditinjau dari salah satu fungsi AAUPPL. sebagai arahan atau patokan bagi pelaksanaan wewenang administrasi negara, untuk memberikan dan menentukan batasbatas yang harus diperhatikan oleh suatu jabatan umum secara hukum, maka AAUPPL dengan sendirinya berorientasi kepada peraturan dan asas-asas tatanan hukum. Sebab, hanya dengan adanya patokanpatokan hukum tersebut kepatuhan terhadap batas-batas jabatan umum dapat dipaksakan, tidak lagi mengharapkan sekedar kesadaran dan keinsyafan pribadi dari pemegang jabatan tersebut. ${ }^{13}$

AAUPPL tersebut bukan merupakan kecenderungan etis atau moral, tetapi merupakan peraturan hukum, juga dapat dirujuk kepada pendapat H.L.A Hart yang membedakan dengan tegas antara moral dan peraturan hukum. ${ }^{14}$ Menurut H.L.A. Hart, peraturan hukum mewajibkan seseorang untuk mengikutinya dan pelanggaran terhadapnya dapat diperkirakan apabila seseorang telah bertindak dengan iktikad baik. Selain itu, peraturan hukum juga merupakan bagian dari kompleks peraturan moral yang tidak membutuhkan adanya hubungan sebab akibat untuk mematuhinya.

P. Nicolai juga cenderung menyatakan bahwa AAUPPL sebagai peraturan hukum, karena AAUPPL itu memiliki fungsi primer sebagai patokan yang berlaku dan hidup dalam penyelenggaraan pemerintahan. walaupun belum memperoleh pengakuan hukum dari hakim. ${ }^{15}$ Meskipun Pendapat $P$. Nicolai ini dikemukakan dalam konteks kehidupan bernegara di Belanda, namun pendapat tersebut sangat bermanfaat untuk dipertimbangkan. Sebab, AAUPPL telah dibuktikan kebenarannya dalam perjalanan penyelenggaraan pemerintahan Belanda. Demikian juga peradilan dan hukum administrasi Belanda telah membuktikan adanya rumusan yang harus diperhatikan oleh

12Lili Rasjidi. 1985. Filsafat Hukum, Apakah Hukum Itu? Bandung: Remadja Karya. HIm. 322: Tatanan Hukum merupakan bagian dari tatanan moral dibantah oleh J. Hoogveld dalam karyanya Hoofdlijnen van de Algemeene Rechisphilosophie.

${ }^{13}$ P. Nicolai. 1990. Beginselen van Berhoorlijk Bestuur. Deventer: Kluver. HIm. 245.

${ }^{14}$ H.L.A Hart. 1981. The Concept of Law. Oxford: Clarendom Press. HIm. 169.

15P. Nicolai. Beginselen van... Op. Cit. Him. 253-254. 
administrasi negaranya untuk memerintah dengan layak. Badan pembentuk undangundang Belanda juga telah memberikan wewenang kepada hakim untuk membatalkan suatu keputusan yang bertentangan dengan AAUPPL, sehingga AAUPPL telah memperoleh sifat daya penerapan untuk lebih didahulukan. Bahkan Centrale Raad van Beroep sebagai hakim pegawai negeri menyarankan agar AAUPPL dapat diterapkan sebagai peraturan. Akhirnya, diharapkan fungsi utama AAUPPL akan memperoleh tempat yang lebih baik lagi, apabila lembaga-lembaga pemerintahan dapat dan selalu mengorientasikan dirinya untuk menerapkan norma-norma yang tertuang dalam AAUPPL.

Di kalangan ilmuwan politik dan administrasi negara, AAUPPL sering disalahartikan sebagai bagian dari asas-asas moral dalam kehidupan politik, utamanya administrasi negara. Hal' ini mudah dipahami mengingat dalam ilmu - politik telah dikembangkan suatu studi tentang etika politik (political ethics) yang berkaitan dengan kehidupan politik pada umumnya, meskipun dalam perkembangannya telah dipersempit lagi pada bidang pemerintahan yang melahirkan etika pemerintahan. ${ }^{16}$

AAUPPL dapat disebut sebagai asas hukum karena mengandung dua unsur penting, yakni asas-asas yang sifatnya etis normatif dan asas-asas yang sifatnya menjelaskan. Asas yang bersifat etis normatif yang terkandung di dalam AAUPPL, menjadikan AAUPPL dapat digunakan sebagai petunjuk untuk melengkapi suatu sifat penting yang mengandung berbagai pengertian hukum, seperti asas persamaan, asas kepastian hukum dan asas kepercayaan. ${ }^{17}$ Asas-asas normatif etis inilah yang mengatur kadar etis di dalam hukum administrasi utamanya dalam penyelenggaraan pemerintahan. Demikian juga karena AAUPPL mengandung asas-asas yang sifatnya memberikan petunjuk dan 'penjelasan terhadap sejumlah peraturan hukum, misalnya asas motivasi:. ${ }^{18}$ Bahkan Hirsch Ballin dengan tegas menyatakan AAUPPL tidak saja berisikan asas-asas, akan tetapi juga merupakan peraturan hukum."

\section{Badan/Pejabat Administrasi Negara yang Membentuk AAUPPL}

Pembentukan dan pemberlakuan AAUPPL melalui penyelenggaraan pemerintahan di Pusat dan di Daerah dilakukan oleh badan atau pejabat administrasi negara. Badan dan Pejabat administrasi negara inilah yang berfungsi dan berperan membentuk AAUPPL, karena badan merupakan sekumpulan orang sebagai kesatuan untuk mengerjakan sesuatu. ${ }^{20}$ Dalam bahasa Belanda, badan atau

'The Liang Gie. 1993. Keadilan Sebagai Landasan Bagi Etika Administrasi Pemerintahan Dalam Negara Indonesia, Jogjakarta: Liberty. HIm.10.

${ }^{17}$ H.D. van Wijk. Hoofdstukken van.... Op. Cit. Him. 70.

${ }^{18}$ Loc. Cit.

i9/bid.

${ }^{20}$ Lihat Anton M. Moeliono. 1990. Kamus Besar Bahasa Indonesia. Jakarta: Balai Pustaka, Dept. Pendidikan dan Kebudayaan R.I HIm. 62. 
lembaga disebut orgaan ${ }^{21}$ yang artinya adalah alat perlengkapan, ${ }^{22}$ sedangkan alat perlengkapan adalah orang atau majelis yang terdiri dari orang-orang yang berdasarkan undang-undang atau anggaran dasar berwenang mengemukakan dan merealisasikan kehendak badan hukum. Selanjutnya, dengan perantaraan alat perlengkapan itu badan hukum turut serta mengambil bagian dalam lalu lintas hukum. ${ }^{23}$ Dengan demikian, orgaan artinya sama dengan badan, sedangkan badan dapat berarti orang atau majelis.

Penggunaan istilah orang berkombinasi dengan majelis dapat menimbulkan konsekuensi, pengertian orang berarti manusia sebagaimana umumnya dan pengertian orang dalam kualitas yuridis. Orang sebagai manusia tidak sinonim dari jabatan karena jabatan bukan sebagai persoon (individu). Demikian juga badan tidak sinonim dari pejabat karena ia baru dapat disebut pejabat apabila bertindak sebagai badan. Karena pejabat yang mewakili pemerintah (negara, propinsi) selalu bergantiganti, maka di antara pejabat dan negara itu dimasukkan pengertian badan yang akan bertindak mewakili pemerintah. ${ }^{24}$ Pendapat ini didukung oleh H.A. Logemann ${ }^{25}$ bahwa apabila pejabat bertindak atas nama jabatannya, maka jabatan itu menjadi pribadi. Artinya, meskipun jabatan itu diwakili oleh pejabatnya tetapi jabatanlah yang dibebani kewajiban dan jabatanlah yang berwenang melakukan perbuatan-perbuatan hukum. Adapun Pejabat artinya adalah pegawai pemerintah yang memegang suatu jabatan penting, seperti departemen, kantor, jawatan, markas.

Dari aspek negara jabatan merupakan suatu organisasi otoritas yang mempunyai fungsi yang saling berhubungan dalam suatu lingkungan kerja tertentu dalam keseluruhan, sehingga atas dasar fungsi inilah H.A. Logemann merumuskan negara sebagai organisasi jabatan yang apabila dimasukkan ke dalam hukum positif akan melahirkan otoriras atau wewenang. Jabatan sebagai bagian dari suatu fungsi atau aktivitas pemerintahan bersifat tetap, berkelanjutan, sedangkan orang atau pejabat (fungsionaris) yang menyandang jabatan itu dapat bergantiganti. ${ }^{26}$ Pendapat ini diikuti oleh F.A.M Stroink dengan mengemukakan beberapa catatan. ${ }^{27}$

2'Lihat D.N. Pattipilohi \& L.M.Petersen. 1991. Indonesisch-Nederlands. Intertaal bv, Amsterdam' Amtenerpen. HIm. 316 .

${ }^{22}$ Lihat N.E. Algra. dkk, Terjemahan Saleh Adiwinata. 1983. Kamus Istilah Hukum Indonesia-Belanda, Fockema Andrea. Jakarta: Binacipta.

${ }^{23}$ Frederik Robert Bohtling. Hel Leerstuk Der Vertegenwoordiging Enzijn Toepassing op Ambtsdragers in Nederiand en in Indonesia.

${ }^{24}$ Loc. Cit.

${ }^{25}$ H.A. Logemann. 1948. "Oder De Theorie van Een Stel Staatsrechtling." Leiden:, Universitaire Pers. Tterjemahan Makkatutu \& Pangkerego. tanpa tahun. Tentang Teori Suatu Hukum Tata Negara. Jakarta: Ichtisar Baru, van Hoeve. Hlm. 104.

${ }^{26} \mathrm{Ibid}$. Hlm. 118.

${ }^{27}$ FAM. Stroink. Deconceiilratie Citeertitel; Het Leestuk De. Deconcentralie, vega-Boekerj. 1978. HIm. 12. 
Pembentukan dan Pemberlakuan AAUPPL melalui Penyelenggaraan Pemerintahan

Ter Haar dalam teori besslissingenleer menyatakan saat terbentuknya adat atau kebiasaan menjadi hukum adat atau hukum kebiasaan, ditentukan melalui proses (cara) tertentu, yaitu existential momentnya. Existential moment terjadi pada saat adat (kebiasaan) itu dituangkan ke dalam suatu ketetapan atau keputusan oleh para fungsionaris hukum.28 Kusumadi Pudjosewojo menerjemahkan istilah fungsionaris hukum (pejabat hukum) dalam arti luas, sehingga mencakup badanbadan atau orang-orang yang bertugas dalam bidang hukum, seperti pembentuk undangundang, hakim, alat-alat perlengkapan tata usaha negara. Dengan demikian, termasuk ke dalam pengertian fungsionaris hukum dalam arti luas adalah Badan atau Pejabat Tata Usaha Negara yang mengeluarkan keputusan (beschikking), peraturan (regeling) dan peraturan kebijakan (beleidsregels) di Pusat dan Daerah.

Pendapat tersebut di atas sejalan dengan kenyataan, bahwa di dalam kehidupan masyarakat memang ditemukan adanya susunan badan-badan atau orang-orang tertentu yang bertugas menentukan, melaksanakan, memperlakukan dan mempertahankan aturan-aturan tingkah laku tertentu yang disebut yang berwajib atau penguasa atau badan/pejabat administrasi negara. ${ }^{29}$

Menurut teori ilmu hukum berlakunya suatu kaidah hukum dapat dibedakan secara filosofis, sosiologis dan juridis. Secara filosofis berlakunya suatu kaidah hukum karena adanya kesesuaian kaidah hukum itu dengan cita-cita hukum sebagai nilai positif yang tinggi, sedangkan secara sosiologis terdapat tiga teori, yaitu: pertama, teori historissosiologis (historisch-sosiologische geltung) dari Gustav Radbruch, menyatakan terjadinya suatu kaidah hukum apabila hal-hal yang faktual hidup di dalam masyarakat berproses menjadi suatu kaidah atau norma.$^{30}$ Kedua, teori kekuasaan (machistheorie), menyatakan berlakunya suatu kaidah hukunl karena,kaidah hukum itu dapat dipaksakan oleh penguasa, meskipun kaidah hukum itu ditolak atau diterima oleh masyarakat. ${ }^{3 i}$ Ketiga, teori pengakuan (anerkenmungs theorie), karena kaidah hukum itu diterima atau diakui oleh masyarakat. ${ }^{32} \mathrm{Di}$, samping itu, masih terdapat adanya teori tentang beriakunya suatu kaidah hukum secara yuridis dikemukan oleh $W$ : Zevenbergen, Hans Kelsen dan J.H.A Logemann.

\footnotetext{
${ }^{28}$ Ter Haar dalam Soejono Soekanto. 1982. Kedudukan dan Peranan Hukum Adat di Indonesia. Jakarta: Jurnia Esa. HIm. 30.

${ }^{29}$ Bushar Muhammad. 1985. Asas-asas Hukum Adat, (Suatu Pengantar). Cetakan ke-5. Jakarta: Pradnya Paramita. Him. 23.

30 Lihat Moh. Koesnoe. 1996. "Lima Puluh Tahun Perjalanan UUD 1945." Varia Peradilan. No. 127. Edisi April. HIm. 141.
}

31/bid. HIm. 142.

${ }^{32}$ Loc. Cit. 
Menurut $W$. Zevenbergen, berlakunya suatu kaidah hukum apabila kaidah hukum tersebut terbentuk sesuai dengan cara-cara yang ditetapkan. Apabila teori ini disambunghubungkan dengan cara terbentuknya secara yuridis AAUPPL yang ditemukan pada bagian formal dan material Surat Keputusan (SK) Presiden (beschikking) selaku Kepala Pemerintahan dan SK Gubernur selaku Kepala Daerah Istimewa Jogjakarta, maka cara terbentuknya AAUPPL pada bagian formal dan material SK Presiden dan Gubernur, telah sesuai dengan cara-cara penyusunan (pembentukan) yang ditetapkan.

Cara-cara yang dimaksud adalah caracara menurut kebiasaan yang selama ini tumbuh dan berkembang dalam. praktek penyusunan SK Presiden dan Gubernur. Kebiasaan tersebut secara terus menerus sungguh-sungguh diperhatikan, diterapkan dan dijadikan patokan atau kriteria objektif dalam penyusunan (pembentukan) setiap SK Presiden dan Gubernur. Pada kenyataannya asas-asas tersebut tidak lagi dipandang sekedar prinsip-prinsip nilai, atau harapanharapan yang dapat dibenarkan untuk ditawarkan dalam penyusunan setiap SK Presiden dạn Gubernur, bahikan sebagai hukum tidak tertulis. Presiden dan Gubernur benar-benar terikat untuk memperhatikan dan menerapkan AAUPPL tersebut dalam penyelenggaraan pemerintahan. Dengan. demikian, berlakunya secara yuridis AAUPPL sebagai kaidah hukum dalam praktek penyelenggaraan pemerintahan adalah sạ.
Pendapat W. Zevenbergen di atas sejalan dengan pendapat Hans Kelsen baḥwa berlakunya suatu kaidah hukum secara yuridis, apabila kaidah hukum tersebut terbentuk sesuai dengan ketentuan atau kaidah hukum yang lebih tinggi. Pembentukan hukum demikian ini merupakan wujud dari tindakan menerapkan hukum. Selanjutnya, apabila pendapat Hans Kelsen ini disambunghubungkan dengan terbentuk dan berlakunya AAUPPL pada bagian formasi dan material SK Presiden dan Gubernur, maka pada kenyataannya ditemukan terbentuknya AAUPPL dalam penyelenggaraan pemerintahan didasarkan pada ketentuan (kaidah) hukum yang lebih tinggi tingkatannya, atau terbentuk karena didasarkan pada atribusi peraturan perundang-undangan yang lebih tinggi. Demikian juga apabila disambunghubungkan dengan ajaran kewenangan dalam hukum administrasi yang mensyaratkan adanya keharusan dalam setiap surat keputusan, maka pendapat Hans Kelsen dan ajaran kewenangan tersebut memiliki persamaan, yakni sama-sama mensyaratkan adanya motivasi-yuridis dalam setiap surat keputusan. ${ }^{33}$

Menurut H.J.A Logemann, secara yuridis berlakunya suatu kaidah hukum, apabila kaidah hukum itu menunjukkan adanya hubungan keharusan antara suatu kondisi dengan akibat-akibat hukum yang ditimbulkannya. Oleh karena itu, apabila keharusan untuk memperhatikan dan menerapkan AAUPPL pada bagian formal dan

${ }^{33}$ Lihat juga B.de Goede. 1986. Beeld van het Nederlands Bestuursrecht. Vuga Uitgeverij, B.V.SGravenhage. Him. 56: Lihat juga P.J.P.Tak. Rechtsvorming in Nederland. Samson H.D. Tjeenk Willink/ Open Universiteit. 
material SK Presiden dan Gubernur DIY, disambunghubungkan dengan akibat-akibat hukum yang akan ditimbulkannya, maka SK Presiden dan Gubernur tersebut dapat dibatalkan oleh Hakim Peradilan Administrasi, karena bertentangan dengan peraturan perundang-undangan yang berlaku, baik bersifat formal-prosedural (non-kontentiosa) maupun bersifat material-substansial (konstentiosa).

Di samping itu, menurut Rustav Radbuch dalam teori historis-sosiologis, berlakunya suatu kaidah hukum, apabila hal-hal faktual atau nyata-nyata hidup dalam masyarakat berproses menjadi suatu kaidah atau norma. Selanjutnya, apabila teori ini disambunghubungkan dengan kenyataan atau fakta yang ditemukan dalam praktek penyelenggaraan pemerintahan ketika menyusun SK Presiden dan Gubernur, maka ditemukan kenyataan bahwa AAUPPL tersebut nyata-nyata hidup dan berkembang dalam praktek pemerintahan di Pusat dan di Daerah.

\section{Simpulan}

Terbentuknya AAUPPL dalam penyelenggaraan, pemerintahan di Pusat dan di Daerah, terjadi melalui berbagai SK Presiden dan Gubernur. Pada bagian forma1 SK tersebut ditemukan AAUPPL bersifat formal berupa asas persiapan cermat, motivasi dan asas larangan penyalahgunaan prosedur, sedangkan pada bagian material ditemukan AAUPPL bersifat material berupa asas kepastian hukum; kepercayaan dan harapan dan asas larangan penyalahgunaan wewenang material ditemukan AAUPPL bersifat material berupa asas kepastian hukum, kepercayaan dan harapan serta asas larangan penyalahgunaan wewenang.

Berlakunya AAUPPL secara yuridis dan sosiologis sebagai kaidah hukum dalam penyelenggaraan pemerintahan di Pusat dan di Daerah melalui SK Presiden dan Gubernur, sesuai dengan cara-cara yang ditentukan menurut kebiasaan yang tumbuh dan berkembang dalam praktek penyelenggaraan pemerintahan. Hal tersebut merupakan kenyataan (faktual) ditemukan dalam praktek penyelenggaraan pemerintahan. Juga sesuai dengan ketentuan atau kaidah hukum yang lebih tinggi atas dasar atribusi. Terakhir, adanya kondisi faktual yang disertai dengan akibat-akibat hukum yang ditimbulkannya, sehingga apabila tidak diperhatikan dapat dibatalkan oleh Hakim Peradilan Administrasi. ב

\section{Daftar Pustaka}

A.M.A. Maasen. tanpa tahun. De Algemmene Beginselen van Berhoorlijk Bestuur. NN, Samsomn. V. Alphenaan Denrijn.

Anton M. Moeliono. 1990. Kamus Besar Bahasa Indonesia. Jakarta: Balai Pustaka, Dept. Pendidikan dan Kebudayaan R.I

B.de Goede. 1986. Beeld van het Nederlands Bestuursrecht. Vuga Uitgeverij, B.V.S-Gravenhage. HIm. 56; Lihat juga P.J.P.Tak. Rechtsvorming in Nederlan'd. Samson H.D. Tjeenk Willink/Open Universiteit.

Bushar Muhammad. 1985. Asas-asas Hukum Adat, (Suatu Pengantar). Cetakan ke-5. Jakarta: Pradnya Paramita. 
D. van Wijk \& Willem Konijnenbelt. 1988. Hoofdstukken van Administratitief Recht, Breda.

D.N. Pattipilohi \& L.M.Petersen. 1991. Indonesisch-Nederlands. Intertaal bv, Amsterdam/Amtenerpen.

E.Sumaryono. 1995. Etika Profesi Hukum, Norma-norma Bagi Penegak Hukum. Jogjakarta: Kanisius.

FAM. Stroink. Deconceiilratie Citeertitel; Het Leestuk De Deconcentralie, vegaBoekerj. 1978.

Frederik Robert Bohtling. Hel Leerstuk Der Vertegenwoordiging Enzijn Toepassing op Ambtsdra-gers in Nederland en in Indonesia.

H. Davos. 1967. "Inleiding tot de Ethiek" (alih bahasa) Soeijono Soemargono. Pengantar Etika. Jogjakarta: Tiara Wacana.

H.A. Logemann. 1948. "Oder De Theorie van Een Stel Staatsrechtling." Leiden:, Universitaire Pers. Tterjemahan Makkatutu \& Pangkerego. tanpa tahun. Tentang Teori Suatu Hukum Tata Negara. Jakarta: Ichtisar Baru, van Hoeve.

H.L.A Hart. 1981. The Concept of Law. Oxford: Clarendom Press.

Lili Rasjidi. 1985. Filsafat Hukum, Apakah Hukum Itu?. Bandung: Remadja Karya.

Mochtar Lubis. 1985. "Kata Pengantar." Dalam Bunga Rampai Korupsi, Jakarta: LP3ES.
Moh Mahfud, MD. 1993. "Perkembangan Politik Hukum. Studi tentang Pengaruh Konfigurasi Politik Terhadap Produk Hukum di Indonesia." Disertasi. Jogjakarta: Universitas Gadjahmada.

Moh. Fajrul Falaakh. 1994. Laporan Penelitian Survey Delegating Proviso dalam Undang-undang Indonesia, 1966-1992. Pusat Antar Universitas Studi Sosial. Jogjakarta: Universitas Gadjah Mada.

Moh. Koesnoe. 1996. "Lima Puluh Tahun Perjalanan UUD 1945." Varia Peradilan. No. 127, Edisi April.

N.E. Algra, dkk, Terjemahan Saleh Adiwinata. 1983. Kamus Istilah Hukum Indonesia-Belanda, Fockema Andrea. Jakarta: Binacipta.

P. Nicolai. 1990. Beginselen van Berhoorlijk Bestuur. Deventer: Kluver.

Robert E. Solomon. 1987. Etika Suatu Pengantar. Jakarta: Erlangga.

Ter Haar dalam Soejono Soekanto. 1982. Kedudukan dan Peranan Hukum Adat di Indonesia. Jakarta: Jurnia Esa.

The Liang Gie. 1986. Etika Administrasi Pemerintahan. Universitas Terbuka.

The Liang Gie. 1993. Keadilan Sebagai Landasan Bagi Etika Administrasi Pemerintahan Dalam Negara Indonesia, Jogjakarta: Liberty.

Wahyudi Kumorotomo. 1992. Etika Administrasi Negara. Jakarta: Rajawali Press. 